\title{
WHAT DO EDUCATIONAL PROFESSIONALS THINK ABOUT GIFTEDNESS? AN ANALYSIS OF ATTITUDES AND REPRESENTATIONS
}

\author{
Stefania Pinnelli, Andrea Fiorucci, \& Clarissa Sorrentino \\ Department of History, Society and Human Studies, University of Salento (Italy)
}

\begin{abstract}
In recent years, studies on teachers' attitudes towards giftedness have become increasingly numerous, though a strong heterogeneity both in the approaches and results. In this direction, focusing on the social dimension of knowledge and on the processes of interpretation and co-construction connected to it, the paper will describe the attitudes toward Giftedness of a sample of 130 Italian education professionals (educators, teachers, pedagogists, psychologists) from North, Centre and South Italy. A specific questionnaire was built to investigate the representations of giftedness. The contribution will explore the main categories of representations connected to Gifted students through an interpretive analysis of qualitative data. We want to verify also if the professional and social role could affect the interpretation of giftedness among the sample of study. Although a great variability is present in the attitudes of the subjects, main dimensions arise in the ideas and imagination of giftedness. The characteristics of the dimensions and how they influence the identification, intervention and education of gifted students is discussed. The contribute reflects on the social representations expressed by the people interviewed about the concept of giftedness and the mental image associated with it. The main differences refer to the meaning of creative thinking and IQ and the image of giftedness as a process of development, growth and plant germination.
\end{abstract}

Keywords: Giftedness, attitudes, teachers, inclusion, social representation.

\section{Social representation of gifted children: the gaze of teachers and educational professionals}

Teachers can contribute significantly to the education of gifted students, enhancing or preventing their potential development (Geake \& Gross, 2008). Molapo and Salyers (2014) show how the success of Gifted education “depends on teachers' attitudes" (p. 191). For this reason, according to Davis and Rimm (2004), the teachers, before taking part in a training or start an educational intervention related to giftedness, should ask themselves the following question: "What is our attitude toward gifted children? (p.55). In recent years, studies on teachers' attitudes towards giftedness have become increasingly numerous, but they have a strong heterogeneity both in the approaches and in the results. In this sense, is important to underline that the attitudes towards an object of knowledge/evaluation, in this case the giftedness, are an individual variation of a collective belief (Salès-Wuillemin, 2006), they are the result of the representations that people create and share during social interaction (Ramel, 2014; Moscovici, 1961; 1984). Although with a very broad analysis object, the theory of social representations (Moscovici, 1961, 1984) offers a remarkable contribution to the study of perceptions on giftedness because it allows reflection on the social dimension of knowledge and on the processes of interpretation and social construction. The representations, in fact, serve to interpret, to "familiarize" (Moscovici, 1984) and socially shareable what we perceive as little known. Like any object of knowledge, even the giftedness can be represented through two processes: 1) anchorage, which allows us to understand what is not familiar, putting it in relation with the interpretative categories already possessed (mathematician, genius, artist, etc.); 2) objectification, which translates into concepts that are difficult to use. The complex and abstract ideas are then objectified through the personification, use of icon-people to represent an idea (Albert Einstein, Leonardo Da Vinci, etc.); figuration, use of concrete images (genius, exclusion, sociopathic) and ontologization, the use of physical or character properties to represent an abstract idea (unkempt hair, goggles, unkempt appearance, introverted character).

In relation to the mentioned processes, there is a international literature review on the representations of giftedness, that shows the most recurrent ideas of the teachers and educational professionals. 
Unfortunately, the most recurring idea is that the gifted pupil can be identified with a very high IQ, in line with the formulation of psychometric models (Mõttus et al., 2008; Heyder, Bergold \& Steinmayr, 2018) or that giftedness is a gift, a predestination (Foley-Nicpon, 2015). Only a small part of the teachers think to giftedness as an opportunity, a possibility, a predisposition to achieve success. It is not a guarantee of success, but rather represents the way to go to "reach it". International literature offers different perspectives on the idea that teachers and educational professionals have giftedness at school: they think of the gifted student as a fragile autodidact (Baudson \& Preckel, 2013), a helpless and immature student, a resource that serves the development of a country (Perković Krijan, Jurčec \& Borić, 2015), a student with special educational needs and which requires specific but not elitist supports (Martin, Burns, \& Schönlau, 2010). In this perspective, the research that follows will try to bring out the representations in a group of italian teachers and educational professionals.

\section{Methods}

The contribution will explore the main categories of representations connected to Gifted students through an interpretive analysis of qualitative data. The socio-demographic variables will be considered in order to understand if the professional role could affect the interpretation of giftedness among the sample of study.

\subsection{Instrument and procedure}

For the survey an ad hoc questionnaire was formulated. After a series of questions aimed at evaluating the demographic characteristics of the sample, two open questions sought to explore the idea of giftedness and the image associated with it:

Q1. What idea do you have of intellectual giftedness? Try to describe it and motivate it.

Q2. Thinking of intellectual giftedness, what image comes to mind?

\subsection{Data analysis}

On the quantitative data a descriptive analysis of the percentage frequencies was carried out, reported in the sample below, while a qualitative analysis was conducted. Through specific reading grids, the hermeneutic-qualitative analysis allowed us to examine and fathom in depth the representations, identifying the key topics. The logical-interpretative assumed plan allowed to analyze the empirical materials acquired according to a sequence of classification operations, initially simple and then composite, aimed at the construction of categories of meaning. The analysis developed on different categorical levels, according to an order of generality/specificity of information. The main objective of the analysis is thematic (Strauss and Corbin, 1998; Kripprendorf, 2004), i.e. the identification of similar concepts, exploring the relationships of meaning. Two cultural repertoires emerged from the analyzed textual corpora, a cognitive and non-cognitive area. The presentation of the results will be developed following the analysis of the different narrative categories that emerged. To make the analysis even clearer, some of the most significant textual extracts are reported.

\subsection{Sample}

The sample taken into consideration in this research consists of 130 participants from different parts of Italy. Specifically, 112 people come from the University of Lecce, 6 from the University of Rome and finally 12 participants from the University of Bologna. The subjects involved are care professionals and possess skills in the psycho-educational and scholastic field. $71 \%$ are teachers, $20 \%$ are educators, $1 \%$ are school principals, $4 \%$ are psychologists, $1.6 \%$ are pedagogists and $4 \%$ are parents. The participants are $92 \%$ females and $8 \%$ males. $29 \%$ of the participants have an age between 20 and 40, 56,4\% had an age between 41 and 60, and $3 \%$ of the participants were over 60 years old. Regarding the sample of teachers, about $37 \%$ teach in second level secondary school, $36 \%$ in primary, $25 \%$ in first grade secondary school and $1.1 \%$ in kindergarten. The majority of teachers $(35 \%)$ teaches more than $19-20$ years, $19 \%$ teaches from $16-19$ years, $17 \%$ work in the field from 11 to 15 years, $15 \%$ from 6 to 10 years, and finally the $14 \%$ are teachers from 0 to 5 years.

\section{Results}

The picture of education professionals' representations is heterogeneous. To the question "What idea do you have of intellectual giftedness?", according to some sample subjects, giftedness is the interaction of several dimensions that are expressed in different ways. It embodies creativity, motivation and exceptional abilities. A gifted person has intuition, problem-solving skills, empathy and divergent 
thinking. In this case we are dealing with answers that explain the giftedness according to a perspective, which could be defined "not cognitive".

Instead according to other subjects, the giftedness concerns above-average cognitive abilities. It also speaks of a high cognitive potential present in the child that manifests itself with a high score in Q.I. The idea of giftedness is that of students having an extra gear on a cognitive level or of subjects with a general skill level far above the average. These expressions are read from a perspective that could be called "cognitive".

Specifically, 39 sample subjects answered according to the cognitive perspective while 54 according to the non-cognitive perspective. In order to more detailed analysis of the conceptions of the sample subjects, it was decided to divide the answers into two main areas:

- cognitive area: whose answers tend to concern the potential and functioning of the psychological abilities of gifted people.

"Students who have a higher gear on a cognitive level, subjects with a level of general ability far above the average, little geniuses".

"Giftedness is the cognitive ability exceptionally superior to the norm that is manifested with a greater mastery of some abilities".

"In my opinion, giftedness is proper to those boys that present a superior IQ due in part to the socio-cultural environment in which they live but above all and innate characteristics of the individual”.

- non-cognitive area: whose answers refer to creativity and socio-environmental and scholastic aspects.

"Gifted is one who has unique and rare qualities and characteristics that can be referred to various aspects of his way of being. Talent, in fact, can refer to a single field of action (theater, dance), but also to several fields of different types".

"Giftedness is divergent thinking, ability to grasp links and relationships in an immediate way, elaboration of other strategies".

"Students able to solve more complex problems than those offered to children of his age, very curious. They do not necessarily excel in all fields and are very creative. Their brain always runs: they invent questions, they make deductions...".

Analyzing the answers of the single subgroups (pedagogists and teachers) this subdivision in the answers remains constant (educators' responses related to cognitive area: (47\%) and non-cognitive area $(53 \%)$, teachers responses related to cognitive area (41\%) and non-cognitive area (59\%). Only in the subgroup of psychologist there is a more tendency toward not cognitive answers, however the limited number of psychologist in the sample cannot give the possibility to generalize this result.

In addition to the subdivision of the answers given by the teachers in the cognitive area and in the non-cognitive area, the teachers themselves were divided according to their specialization on the Special Education or in The Curricular area. In general, 39 teachers have the SEN specialization and 34 are curricular teachers. As regards teachers with SEN specialization $51 \%$ of the answers are related to the non-cognitive area, $49 \%$ to the cognitive area. On the other hand, $68 \%$ of curricular teachers without specialization in SEN responded according to a non-cognitive perspective, the remaining $32 \%$ according to a cognitive perspective.

Thinking to the image of giftedness (the second question of the survey), in general, for all the subjects of the sample, giftedness is imagined as a combination of skill and intelligence above average.

Starting with the subgroup of educators and educators, it focuses on the educational aspect and considers the social and scholastic context in promoting giftedness. Likewise, without the contribution of the environment, giftedness can turn into a failure for the person. Failed education and care

Some answers given by educators are reported below:

"The image I think of is that of the so-called "geniuses" who are so excellent, as they are sometimes hindered precisely because they do not know how to manage and make the most of their skills and abilities".

"I imagine geniuses that have marked abilities above the average and present excellences in one or more areas. When they are identified, they should be encouraged and improved in their academic career"

"Thinking of the giftedness, I remember "Lisa Simpson", a girl far ahead of her age forced to adapt to the "normality" of her class". 
The sub-group of teachers, like that of educators, attaches importance to school education, but at the same time considers giftedness as a "problem" to be addressed. The teachers report that they are unprepared to deal with this "particularity" but they would be in favor of further exploring the theme to identify the specific needs of gifted children. Below some of the answers of the teachers are reported:

Teacher A: "Giftedness makes me think of something exciting but at the same time complex and challenging”.

Teacher B: "These gifted children are very often mistaken for behavioral disorders so that for them to a specialized plan and learning paths designed for them would be necessary".

Teacher C: "Teachers must also be trained on giftedness: the inadequacy of teachers and educators comes to my mind".

Teacher D: "A rough diamond that shines brightly and preciously."

Teacher E: "A swollen river".

\section{Conclusions}

The study reveals a partial idea of the giftedness that is often divided between cognitive and non-cognitive aspects. Giftedness is instead a multidimensional concept, which embraces numerous characteristics such as creativity, intelligence, motivation, leadership (Renzulli, 1978) and which can relate to both aspects, often leading to situations of asynchronous development (Kreger Silverman, 1997).

In the description of the images the attention therefore shifts to the management of the problems created by the gifted pupil, seen as a flooding river, often mistaken for pupils with behavioral problems. It is interesting to note that the image of teachers is self-centered to their role and that consequently the gifted child or boy is seen as a problem that the school must face "so that a diamond can then become a jewel". Hence the need for educational didactic tools for teachers, a school planning attentive to the peculiarities of these students (Renzulli, 1977, 2012), who find teachers who are not prepared to deal with these requests. The first step is to recognize who is a gifted student, starting from a deep knowledge of the phenomena and its characteristics in order to build the capacity of teachers to create meaningful opportunities for these children. This aspect must be translated into knowledge of giftedness and into operation towards giftedness, i.e. education professionals have the task of getting around and responding to educational needs even born from school excellence. The first step is certainly to recognize a talent, but beyond any possible label it is necessary to satisfy the educational needs of the gifted student who enters into relationship with his family, with his experiences and life contexts, avoiding any possible stigmatization or myth of his diversity. In this direction, the history of Italian scholastic integration is a teacher, it teaches everyone that the needs of a student, albeit a talented one, reflect those of a student's life, a life of dreams and fears, achievements and defeats, friendships and enmities, support and autonomy. The article, therefore, pushes us to reflect three emerging themes: creating a positive, constructive and supportive learning environment; offering a cognitively challenging curriculum; and engaging the learners in partnership to understand and manage their learning support.

Gifted students should have great importance and they should be given great attention in terms of social, emotional, cognitive adequateness, interests and abilities. For that reason, the education they took is one of the priorities for their developmental needs so as to provide them the opportunities they need in educational environments. Moreover, the education should be seen as a critical process consisting of identification, assessment, but above all in a competent and loving guidance.

How do educational professionals develop an instructional and education plan that will be challenging, enlightening, and intriguing to students of different abilities, and still maintain a sense of community within the classroom or social aggregate? This is the central question for educators as they begin to work in this educational field.

\section{References}

Baudson T. G., Preckel. F. (2013). Teachers' implicit personality theories about the gifted: An experimental approach. School Psychology, 28(1), 37-46.

Davis G., Rimm, S. (2004). Education of the gifted and talented. USA: Allyn \& Bacon.

Foley-Nicpon, M., Assouline, S. G., \& Fosenburg, S. (2015). The Relationship Between Self-Concept, Ability, and Academic Programming Among Twice-Exceptional Youth. Journal of Advanced Academics, 26(4), 256-273.

Geake, J. G., Gross, M. U. (2008). Teachers' Negative Affect Toward Academically Gifted Students an Evolutionary Psychological Study. Gifted Child Quarterly, 52(3), 217-231. 
Heyder, A., Bergold, S., \& Steinmayr, R. (2018). Teachers' Knowledge About Intellectual Giftedness: A First Look at Levels and Correlates. Psychology Learning \& Teaching, 17(1), 27-44.

Kreger Silverman, L. (1997). The construct of asynchronous development. Peabody Journal of Education. 72. 36-58.

Kripprendorf, K. (2004), Content analysis. An introduction to its methodology. Thousand Oaks, CA: Sage.

Martin, L., Burns, R., Schonlau, M. (2010). Mental disorders among gifted and nongifted youth: A selected review of the epidemiologic literature. Gifted Child Quarterly, 54, 31-41.

Molapo T. P., Salyers M. (2014). Parent-teacher Shared Commitment as a Predictor for Teachers' Attitudes toward Gifted Students and Gifted Education. Journal of Studies in Education, 4(1), 190-205.

Moscovici S. (1961). La psychanalyse, son image et son public. Paris: Presses Universitaires de France.

Moscovici S. (1984). The Phenomenon of Social Representations. In R. Farr, S. Moscovici (Eds). Social representations. Cambridge: Cambridge University Press.

Mõttus, R., Allik, J., Konstabel, K., Kangro, E.-M., \& Pullmann, H. (2008). Beliefs about the relationship between personality and intelligence. Personality and Individual Differences, 45, 457- 462.

Perković Krijan I., Jurčec L., Borić E. (2015) Primary School Teachers’ Attitudes toward Gifted Students. Croatian Journal of Education 17(3), 681-724.

Ramel S. (2014). Elèves en situation de handicap ou ayant des besoins éducatifs particuliers: quelles représentations chez de futurs enseignants? Revue suisse de pédagogie spécialisée, n. 3, pp. 20-26.

Reis, S., Mc Coach, D., (2000). The underachievement of gifted students: What do we know and where do we go? Gifted Child Quarterly, NAGC, Vol. 44, N. 3,

Renzulli J. (1978). What makes giftedness, Phi Delta Kappan 60, n. 3.

Renzulli J. (2012). Reexamining the role of the gifted education and talent development for the 21st century: a four part of theoretical approach, Gifted child quarterly, vol. 56.

Renzulli J. (1977). The enrichment triad model: A guide for developing defensible programs for the gifted and talented. Mansfield Center, CT: Creative Learning Press.

Salès-Wuillemin E. (2006). La catégorisation et les stéréotypes en psychologie sociale. Paris: Dunod.

Strauss, A., Corbin, J. (1998), Basics of Qualitative Research. Thousand Oaks, CA: Sage Publications. 